\title{
Pendekatan Matematika Realistik (PMR) Dalam Meningkatkan Prestasi Belajar Matematika Siswa Kelas V SD Negeri 17 Parepare
}

\author{
Zaid Zainal \\ Program Studi PGSD Fakultas Ilmu Pendidikan Universitas Negeri Makassar \\ zainal.zaid@gmail.com
}

\begin{abstract}
The aims of this research to determine the learning outcome math class V students of SD Negeri 17 Parepare using the approach Realistic Mathematics (PMR). The research used qualitative descriptive and type of research is the Classroom Action Research (PTK) cyclical which includes planning, implementation, observation, and reflection. The subjects of this research were fifth grade students of SD Negeri 17 Parepare, in the first semester of academic year 2016/2017 with 30 students. The experiment was conducted on two cycles, the first cycle during the 4 meetings and the second cycle during the 4 meetings. Data was collected using achievement test at the end of the first cycle and the end of the second cycle and by using observation sheet and questionnaire responses of students. The results of quantitative analysis showed that the average score of the mathematics learning outcomes Elementary School fifth grade students at the end of cycle 17 Parepare I was in the moderate category. At the end of the second cycle, the average score of students' mathematics learning outcomes at the high category. Qualitatively, there is increased presence and activity of students in learning. Based on these results it can be concluded that with the implementation of realistic mathematics approach can improve mathematics achievement fifth grade students of SD Negeri 17 Parepare.
\end{abstract}

Keywords: Realistic Mathematics Education, Achievement

PENDAHULUAN
Salah satu permasalahan yang dihadapi oleh Bangsa Indonesia adalah rendahnya mutu pendidikan pada setiap jenjang dan satuan pendidikan khususnya pendidikan dasar dan menengah. Untuk itu peningkatan mutu pendidikan nasional merupakan kebutuhan yang seharusnya menjadi prioritas utama dalam program pembangunan bangsa.

Fenomena rendahnya mutu pendidikan secara sistematis dapat ditelaah dari aspek input, proses, dan output. Perbaikan, pengembangan, dan inovasi pendidikan ketiga aspek tersebut membutuhkan sumber daya manusia yang berkualitas. Keberhasilan dalam proses belajar-mengajar matematika tidak terlepas dari kesiapan peserta didik dan kesiapan pengajar, peserta didik dituntut untuk mempunyai minat terhadap pelajaran matematika demikian juga pengajar dituntut menguasai materi yang akan diajarkan serta mampu memilih metode pembelajaran yang tepat sehingga akan tercipta interaksi edukatif yang baik menuju kearah peningkatan hasil belajar matematika, namun hingga saat ini hasil belajar matematika masih belum maksimal, terutama pada tingkat Sekolah Dasar (SD).

Pemilihan metode yang tepat sangat membantu keberhasilan proses belajar mengajar di kelas. Namun yang terpenting bahwa hal itu dapat menimbulkan perhatian dan motivasi siswa untuk belajar, sebab tanpa adanya perhatian dan motivasi belajar maka kualitas pembelajaran yang dicapai siswa belum optimal. Oleh karena itu, guru mempunyai peranan yang sangat menentukan dalam mengarahkan siswa untuk mencapai tujuan yang diharapkan. Sebab gurulah yang secara langsung membimbing dan mengarahkan siswa untuk belajar melalui bahan pengajaran yang diberikan dengan metode yang sesuai.

Menurut Peraturan Menteri Pendidikan Nasional (2006) yang menyebutkan bahwa salah satu tujuan pembelajaran matematika adalah memahami konsep matematika, sehingga guru harus mampu membuat siswa paham akan konsep matematika bukan hanya sekadar hafal saja. Gunawan (2013a) menyebutkan bahwa RME adalah suatu teori pembelajaran matematika yang beranggapan bahwa matematika adalah aktivitas manusia serta matematika harus dihubungkan terhadap 
konteks kehidupan sehari-hari siswa yang menggunakan proses matematisasi horizontal maupun vertikal untuk mengembangkan konsep dan mengaplikasikannya. Pendapat lain menyebutkan bahwa, pendekatan matematika realistik merupakan pendekatan pembelajaran yang berorientasi pada penalaran siswa dalam menyelesaikan masalah yang bersifat realistik yang ditujukan untuk mengembangkan pola pikir praktis, logis, kritis, dan jujur (Tarigan, 2006).

Berdasarkan pendapat di atas maka dapat disimpulkan bahwa, pendekatan matematika realistik adalah pendekatan pembelajaran yang berorientasi pada aktivitas pengkonstruksian pengetahuan dengan menghubungkan antar konsep untuk memecahkan masalah yang berhubungan dengan aktivitas manusia yang berguna untuk mengembangkan pola pikir praktis, logis, kritis, dan jujur dengan menggunakan konteks dari lingkungan dalam mengajarkan konsepnya. Oleh karena itu dalam pendekatan realistik masalah yang berhubungan dengan dunia nyata siswa diangkat sebagai titik awal pembelajaran dan siswa dituntut untuk mampu memecahkan masalah agar dapat menemukan konsep yang diajarkan.

Penelitian sebelumnya dilakukan oleh Jufriyah, R. (2008) di SDN 1 Lungbenda Kecamatan Palimanan Kabupaten Cirebon, serta penelitian yang dilakukan oleh Humardani (2010) di Kecamatan Susukan Kabupaten Cirebon, nenunjukkan rendahnya kemampuan pemecahan masalah dan pemamhaman konsep matematika siswa. Sejalan dengan itu sebagai langkah awal penulis melakukan penelitian/pengamatan di SD Negeri 17 Parepare. Hasil wawancara dengan guru Matematika mengatakan bahwa rata-rata kualitas pembelajaran matematika siswa kelas V SD Negeri 17 Parepare tergolong rendah, sebagaimana dokumentasi hasil belajar siswa kelas $\mathrm{V}$ pada semester ganjil 2014/2015 hanya mencapai rata-rata 5,31 . Selain itu, pendekatan yang digunakan oleh guru matematika masih bersifat pendekatan tradisional atau mekanistik yaitu guru menerangkan dan lebih mendominasi selama proses belajar mengajar, sedangkan siswa lebih banyak mencatat. Akibatnya siswa kurang dan bahkan tidak mampu mengembangkan pengetahuannya karena mereka terfokus pada apa yang diberikan oleh guru. Ketika siswa tersebut dihadapkan pada permasalahan yang berbeda dengan yang telah diajarkan oleh guru, mereka akan mengalami kesulitan. Hal tersebut diduga sebagai salah satu penyebab rendahnya prestasi belajar khususnya dalam pembelajaran matematika.

Salah satu alternatif untuk meningkatkan kualitas pembelajaran matematika siswa Kelas V SD Negeri 17 Parepare yaitu dengan menerapkan pembelajaran melalui pendekatan realistik. Dengan pendekatan realistik diharapkan dapat mengubah kualitas belajar siswa terhadap matematika menjadi lebih berinisiatif, kreatif, dan aktif dalam kegiatan pembelajaran. Pada pendekatan realistik ini diberikan buku siswa tentang materi pecahan (penjumlahan, pengurangan, pembagian, dan perkalian) sebagai media pembelajaran agar siswa lebih cepat memahami dan mengerti mengenai materi yang diajarkan oleh guru.

\section{Realistic Mathematics Education}

(RME) merupakan salah satu pendekatan dalam pembelajaran matematika. RME pertama kali dikembangkan di Belanda pada tahun 1971 oleh Institut Freudhental (Sembiring, dkk.2010). Pendekatan ini mengacu pada pendapat Freudenthal yang mengatakan bahwa matematika harus dikaitkan dengan realita dan matematika merupakan aktivitas manusia.

Hal ini berarti bahwa matematika harus dekat dengan anak dan relevan dengan kehidupan nyata sehari-hari. Gravemeijer mengemukakan bahwa matematika sebagai aktivitas manusia berarti manusia harus diberi kesempatan untuk menemukan kembali ide dan konsep matematika dengan bimbingan orang dewasa. Menurut Slettenhaar (dalam Suharta, 2003) berbagai upaya yang dilakukan melalui penjelajahan berbagai situasi dalam persoalan-persoalan realistik. Realistik dalam hal ini dimaksudkan tidak mengacu pada realitas tetapi pada sesuatu yang dapat dibayangkan oleh siswa. Prinsip penemuan kembali dapat diinspirasikan oleh prosedurprosedur pemecahan informal, sedangkan proses penemuan kembali menggunakan konsep matematisasi.

Prinsip pendekatan matematika realistik disampaikan oleh Suryanto, dkk. (2010) yaitu: a) guided re-invention (penemuan kembali secara terbimbing) dan progressive Mathematization (matematisasi progresif); b) didactical phenomenology (fenomenologi didaktis); serta c) self-developed model (membangun sendiri model). Maksudnya adalah melalui masalah realistik yang diberikan guru, siswa dibimbing untuk menemukan kembali konsep matematika melalui kegiatan matematisasi horizontal dan vertikal. Tujuan utama pendekatan matematika realistik adalah 
pengalaman belajar yang bermakna bagi siswa dan sikap positif siswa terhadap matematika. Karena siswa memiliki kebebasan dalam memecahkan masalah realistik yang disajikan guru, maka sangat memungkinkan siswa mengembangkan model sendiri.

Rober Sembiring (2010) menerangkang tentang pelaksanaan konsep pelaksanaan PMR kaitannya terhadap guru dan siswa adalah sebagai berikut:

1). Konsepsi RME tentang siswa dalam proses belajar mengajar:

(a). Siswa memiliki seperangkat konsep alternatif tentang ide-ide matematika yang mempengaruhi belajar selanjutnya.

(b). Siswa memperoleh pengetahuan baru dengan membentuk pengetahuan itu untuk dirinya sendiri.

(c). Pembentukan pengetahuan merupakan proses perubahan yang meliputi penambahan, kreasi, modifikasi, penghalusan, penyusunan kembali dan penolakan.

(d). Pengetahuan baru yang dibangun oleh siswa untuk dirinya sendiri berangkat dari seperangkat ragam pengalaman.

(e). Setiap siswa tanpa memandang ras, budaya dan jenis kelamin mampu memahami dan mengerjakan matematika.

2). Konsepsi RME tentang guru dalam proses belajar mengajar:

(a). Guru hanya sebagai fasilitator belajar.

(b). Guru harus mampu membangun pengajaran interaktif.

(c). Guru harus memberikan kesempatan kepada siswa untuk secara aktif menyumbangkan ide pada proses belajar dirinya, dan secara aktif membantu siswa dalam menafsirkan persoalan real.

(d). Guru tidak terfokus pada materi yang termaktub dalam kurikulum, melainkan aktif dalam mengaitkan kurikulum dengan dunia real, baik fisik maupun sosial.

3). Konsepsi tentang pengajaran matematika dengan pendekatan RME meliputi aspekaspek berikut:

(a). Memulai pelajaran dengan mengajukan masalah yang real bagi siswa sesuai dengan pengalaman dan tingkat pengetahuannya, sehingga siswa segera terlibat dalam pembelajaran secara bermakna.

(b). Permasalahan yang diberikan harus diarahkan sesuai dengan tujuan yang ingin dicapai dalam pelajaran tersebut. (c). Siswa mengembangkan model-model simbolik secara informal terhadap persoalan/ masalah yang diajukan.

(d). Pengajaran berlangsung secara interaktif yaitu siswa menjelaskan dan memberikan alasan terhadap jawaban yang diberikannya, memahami jawaban temannya, setuju terhadap jawaban temannya, menyatakan ketidaksetujuan, mencari alternatif penyelesaian yang lain dan melakukan refleksi terhadap setiap langkah yang ditempuh atau terhadap hasil pembelajaran.

\section{METODE PENELITIAN}

Penelitian ini adalah penelitian tindakan kelas dengan faktor kajian peningkatan hasil belajar matematika siswa melalui Pendekatan Matematika Realistik Pelaksanaannya dibagi dalam dua siklus dengan 4 (empat) tahap yaitu perencanaan, tindakan, observasi dan refleksi.

Penelitian ini dilaksanakan pada siswa kelas V SD Negeri 17 Parepare tahun ajaran 2016/2017, dengan jumlah siswa 30 orang yang terdiri dari 16 orang siswa wanita dan 14 orang siswa pria.

Adapun teknik pengumpulan data yang digunakan dalam penelitian ini adalah: Data hasil belajar diperoleh dengan memberikan tes kepada siswa, sedangkan sedangkan data mengenai perubahan sikap, kesungguhan dan keaktifan siswa dalam mengikuti kegiatan belajar mengajar diperoleh dengan cara pengamatan dan observasi.

Data yang diperoleh dianalisis dengan menggunakan analisis kuantitatif dan kualitatif. Untuk analisis kuantitatif digunakan analisis SPSS for Windows (SPSS 20.0 for windows) yaitu skor rata-rata, standar deviasi, tabel frekuensi, nilai minimum dan nilai maksimum yang diperoleh siswa pada setiap siklus.

\section{HASIL \& PEMBAHASAN}

\section{Hasil Penelitian}

Pendekatan matematika realistik yang diterapkan dalam pembelajaran matematika untuk siswa kelas IV SD Negeri 17 Parepare telah dilakukan selama dua siklus dalam kegiatan penelitian yang ditelah direncanakan. Hasil belajar sebagai bagian utama dari tujuan pembelajaran yang diharapkan dapat memberikan hasil maksimal, sehingga target pembelajaran yang ditentukan dapat tercapai dengan baik.

\section{Deskripsi hasil belajar matematika pada siklus I}


Berdasarkan hasil penelitian yang telah dilakukan, kemudian dianalisis dengan menggunakan perangkat perhitungan statistika. Hasil analisis statistika deskriptif diperoleh; Mean $=56.2$, Median $=57.1$, modus $=55.2$, dan standar deviasi $=10.6$.

Hasil analisis tersebut menunjukkan kalau hasil belajar siswa kelas V SD Negeri 17 Parepare berada dalam kategori sedang, sesuai dengan teknik pengkategorian yang digunakan dalam teknik analisis data yang dikemukakan sebelumnya.

Apabila hasil belajar siswa dikelompokkan ke dalam tabel pengkategorian, akan diperoleh hasil sebagai berikut.

Tabel : Distribusi Frekuensi dan Persentase

Skor Hasil Belajar Matematika Siswa pada Siklus I

\begin{tabular}{llcc}
\hline \multicolumn{1}{c}{ Skor } & Kategori & Frekuensi & Persentase (\%) \\
\hline $0-34$ & Sangat rendah & - & - \\
$35-54$ & Rendah & 2 & 6,67 \\
$55-64$ & Sedang & 20 & 66,67 \\
$65-84$ & Tinggi & 5 & 16,67 \\
$85-100$ & Sangat Tinggi & 3 & 10,00 \\
\hline \multicolumn{2}{c}{ Jumlah } & $\mathbf{3 0}$ & $\mathbf{1 0 0}$ \\
\hline
\end{tabular}

Kegiatan pembelajaran pada siklus I, tidak hanya memperhatikan nilai yang diperoleh siswa pada siklus I setelah menerima materi pembelajaran yang selanjutnya diberikan tes, yang dikenal tes siklus I.

Dari hasil yang dikemukakan dalam tiap pertemuan pembelajaran pada siklus I di atas, tampak bahwa hasil observasi kegiatan pembelajaran siswa dapat direkapitulasi dengan rata-rata sebagai berikut:

a) Untuk kehadiran siswa dalam kegiatan pembelajaran tampak rata-rata sebanyak 30 orang untuk keseluruhan pertemuan.

b) Untuk kemampuan mengkontruksi jawaban, tampak rata-rata sebanyak 19 orang untuk keseluruhan pertemuan.

c) Untuk kemampuan mengidentifikasi dan memahami masalah yang diberikan, tampak rata-rata sebanyak 24,25 atau sekitar 25 orang dari keseluruhan pertemuan.

d) Untuk kemampuan mengajukan pertanyaan tentang materi yang diberikan, tampak rata-rata sebanyak 8 orang dari keseluruhan pertemuan.

e) Untuk kemampuan memberikan jawaban terhadap permasalahan yang diberikan, tampak rata-rata sebanyak 3,5 atau sekitar 4 orang dari keseluruhan pertemuan.

f) Untuk kemampuan menyimpulkan terhadap permasalahan yang diberikan, tampak rata-rata sebanyak 4 orang dari keseluruhan pertemuan.

g) Untuk siswa yang mengerjakan tugas dari guru, tampak rata-rata sebanyak 41,5 atau sekitar 27 orang dari keseluruhan pertemuan. h) Untuk siswa yang mengemukakan jawabannya di papan tulis, tampak ratarata sebanyak 5 orang dari keseluruhan pertemuan.

i) Untuk siswa yang memberikan tanggapan terhadap jawaban yang diberikan, tampak rata-rata sebanyak 4 orang dari keseluruhan pertemuan.

j) Untuk siswa yang mengerjakan pekerjaan rumah yang diberikan, tampak rata-rata sebanyak 33,5 atau sekitar 25 orang dari keseluruhan pertemuan.

\section{Deskripsi hasil belajar matematika pada siklus II}

Berdasarkan hasil penelitian yang telah dilakukan, kemudian dianalisis dengan menggunakan perangkat perhitungan statistika. Hasil analisis statistika deskriptif diperoleh; Mean $=78.8$, Median $=81.1$, Modus $=76.2$, Standar Deviasi $=9.9$.

Berdasarkan hasil analisis yang dikemukakan di atas, tampak kalau kegiatan pembelajaran matematika yang dilakukan pada siklus II merupakan kelanjutan daripada siklus I. Untuk hasil belajar matematika siswa yang dilakukan pada siklus II, diukur dengan indikator deskriptif menunjukkan kenaikan yang sangat signifikan yakni menjadi kategori tinggi.

Apabila hasil belajar siswa dikelompokkan ke dalam tabel pengkategorian, akan diperoleh hasil sebagai berikut. 
Tabel : Distribusi Frekuensi dan Persentase

Skor Hasil Belajar Matematika Siswa pada Siklus II

\begin{tabular}{|c|c|c|c|}
\hline Skor & Kategori & Frekuensi & Persentase (\%) \\
\hline $0-34$ & Sangat rendah & - & - \\
\hline $35-54$ & Rendah & 1 & 3,33 \\
\hline $55-64$ & Sedang & 5 & 16,67 \\
\hline $65-84$ & Tinggi & 20 & 66,67 \\
\hline $85-100$ & Sangat Tinggi & 4 & 13,33 \\
\hline \multicolumn{2}{|c|}{ Jumlah } & 30 & 100 \\
\hline
\end{tabular}

Dari hasil yang dikemukakan dalam tiap pertemuan pembelajaran pada siklus II di atas, tampak bahwa hasil observasi kegiatan pembelajaran siswa dapat direkapitulasi dengan rata-rata sebagai berikut:

a) Untuk kehadiran siswa dalam kegiatan pembelajaran tampak rata-rata sebanyak 30 orang untuk keseluruhan pertemuan.

b) Untuk kemampuan mengkontruksi jawaban, tampak rata-rata sebanyak 23 orang untuk keseluruhan pertemuan.

c) Untuk kemampuan mengidentifikasi dan memahami masalah yang diberikan, tampak rata-rata sebanyak 29 orang dari keseluruhan pertemuan.

d) Untuk kemampuan mengajukan pertanyaan tentang materi yang diberikan, tampak rata-rata sebanyak 10 orang dari keseluruhan pertemuan.

e) Untuk kemampuan memberikan jawaban terhadap permasalahan yang diberikan, tampak rata-rata sebanyak 5 orang dari keseluruhan pertemuan.

f) Untuk kemampuan menyimpulkan terhadap permasalahan yang diberikan, tampak rata-rata sebanyak 5 orang dari keseluruhan pertemuan.

g) Untuk siswa yang mengerjakan tugas dari guru, tampak rata-rata sebanyak 28 orang dari keseluruhan pertemuan.

h) Untuk siswa yang mengemukakan jawabannya di papan tulis, tampak ratarata sebanyak 5 orang dari keseluruhan pertemuan.

i) Untuk siswa yang memberikan tanggapan terhadap jawaban yang diberikan, tampak rata-rata sebanyak 5 orang dari keseluruhan pertemuan.

j) Untuk siswa yang mengerjakan pekerjaan rumah yang diberikan, tampak rata-rata sebanyak 29 orang dari keseluruhan pertemuan.

\section{Pembahasan Hasil Penelitian}

Berdasarkan hasil analisis deskriptif yang dikemukakan di atas, terdapat dua hal penting dalam hasil kegiatan penelitian yang telah dilakukan, yaitu a) perubahan hasil belajar matematika siswa secara kuantitatif, dan b) perubahan hasil belajar matematika siswa secara kualitatif. Adapun perubahan yang lebih terperinci di uraikan sebagai berikut:

\section{Perubahan hasil belajar matematika siswa secara kuantitatif}

Hasil belajar matematika siswa kelas V SD Negeri 17 Parepare mengalami peningkatan dari segi kuantitas, walaupun tetap berada dalam kategori sedang, yakni pada siklus I rata-rata nilai hasil belajar siswa, yaitu 56,2 dengan standar deviasi sebesar 10,6. Kemudian pada siklus II rata-rata nilai hasil belajar siswa, yaitu 78,8, dengan standar deviasi 9,9 berada pada kategori tinggi. Dengan demikian, selisih nilai rata-rata hasil belajar siswa kelas V SD Negeri 17 Parepare sebesar 22,6. Hal ini berarti perbedaan kemampuan belajar siswa antara siklus I dan siklus II dengan diterapkannya Pendekatan matematika realistik dalam kegiatan pembelajaran matematika sebesar 22,6.

Hasil belajar matematika siswa kelas V SD Negeri 17 Parepare memang mengalami peningkatan yang cukup berarti. Sebab selisih 22,6 menandakan bahwa siswa mau belajar didukung dengan aktivitas yang membangkitkan minat mereka untuk belajar dengan baik. Pendekatan matematika realistik mampu berpengaruh untuk meningkatkan kuantitas hasil belajar siswa.

\section{Perubahan hasil belajar matematika siswa secara kualitatif}

Selain perubahan hasil belajar yang ditunjukkan secara kuantitatif, juga dukungan dari hasil observasi terhadap aktivitas belajar siswa dan aktivitas memfasilitasi oleh guru. Dalam kegiatan pengamatan yang dilakukan terdapat beberapa hal menarik yang terjadi selama pembelajaran berlangsung, diantaranya:

a) Guru yang menyampaikan indikator pembelajaran dapat merangsang pengalaman belajar siswa, sehingga siswa 
mengetahui langkah kegiatan yang hendak dicapai pada pertemuan tersebut.

b) Guru yang melakukan rangsangan pengetahuan awal siswa melalui interaksi tersebut dapat merangsang semangat belajar siswa, sehingga siswa memahami topik pembelajaran yang hendak dikaji pada pertemuan tersebut.

c) Guru yang menggunakan media dalam kegiatan pembelajaran juga dapat merangsang semangat belajar siswa, sehingga siswa tertarik untuk ikut dalam kegiatan pembelajaran pada pertemuan tersebut.

d) Ada hal yang menarik dalam penerapan Pendekatan matematika realistikyang diterapkan dapat membangkitkan semangat belajar siswa, sehingga meminimalisir jumlah siswa yang melakukan kegiatan selain pembelajaran.

e) Guru yang selalu menuntun siswa agar memahami kegiatan pembelajaran yang hendak dilakukan. Sehingga dalam kegiatan pembelajaran, siswa mampu memahami materi pembelajaran dan siswa memahami langkah-langkah yang dilakukan dalam mempelajari materi pembelajaran tersebut.

f) Guru yang selalu menuntun siswa agar memahami kegiatan pembelajaran yang hendak dilakukan sesuai dengan lembar kegiatan siswa yang sengaja disiapkan. Sehingga berdasarkan hal tersebut, tampak siswa meminati proses yang dilakukan karena cukup dengan melihat lembar kegiatan yang dimiliki, mereka dapat mengetahui kegiatan apa selanjutnya yang akan dilakukan oleh siswa.

Keenam perubahan aktivitas tersebut menjadi hasil observasi yang tampak dalam penerapan Pendekatan matematika realistikdi kelas V SD Negeri 17 Parepare. Sehingga peneliti menyimpulkan bahwa dengan menerapkan Pendekatan matematika realistik mampu memberikan perubahan bukan hanya meningkatkan hasil belajar matematika dari segi kuantitas tetapi juga hasil belajar secara berkualitas. Kemudian dampaknya berimbas pada guru, siswa, dan interaksi pembelajaran.

\section{KESIMPULAN \& SARAN}

\section{A. Kesimpulan}

Berdasarkan hasil analisis data dan pembahasan, maka dapat ditarik kesimpulan bahwa kualitas pembelajaran matematika siswa Kelas V SD Negeri 17 Parepare dapat mengalami peningkatan melalui pelaksanaan pembelajaran dengan menggunakan Pendekatan Matematika Realistik

Adapun hasil penelitian yang dilaksanakan selama dua siklus ini dapat diidentifikasikan sebagai berikut:

1. Kualitas pembelajaran matematika siswa kelas V SD Negeri 17 Parepare pada akhir siklus I rata-rata nilai hasil belajar siswa, yaitu 56,2 dari skor ideal 100, dengan standar deviasi sebesar 10,6. Kemudian pada siklus II rata-rata nilai hasil belajar siswa, yaitu 78,8 dari skor ideal 100 dengan standar deviasi 9,9 berada pada kategori tinggi.

2. Terjadi peningkatan frekuensi kesungguhan siswa (perhatian siswa dalam mengikuti pelajaran dan mengerjakan pekerjaan rumah) serta keaktifan siswa (bertanya pada saat pembelajaran berlangsung dan mengerjakan soal di kelas) dalam proses belajar mengajar sesuai dengan hasil observasi selama tindakan dilaksanakan maupun dari hasil refleksi siswa.

\section{B. Saran}

Sesuai dengan hasil yang diperoleh dari penelitian ini, diajukan saran-saran sebagai berikut :

1. Kepada guru SD:

a. Sebaiknya guru dalam mengajar, tidak hanya terpusat pada satu metode saja, melainkan menggunakan beberapa metode.

b. Kiranya pembelajaran matematika realistik dapat diterapkan untuk peningkatan hasil belajar matematika siswa, dan dapat dipertimbangkan sebagai salah satu alternatif pembelajaran dalam proses belajar mengajar matematika.

c. Dalam penerapan pembelajaran matematika realistik agar selalu mendorong siswa untuk mengaitkan apa yang sedang dipelajari dengan pengetahuan/ pengalaman yang telah dimiliki siswa sebelumnya (materi prasyarat) dan siswa didorong untuk membangun kesimpulan yang merupakan pemahaman siswa terhadap suatu konsep atau teori yang sedang dipelajari.

Keberhasilan pembelajaran dengan pendekatan matematika realistik banyak dipengaruhi oleh motivasi siswa dalam mengikuti proses pembelajaran. Karena itu, disarankan kepada guru yang melaksanakan pembelajaran agar berupaya mengaktifkan motivasi siswa melalui apresiasi awal tiap pertemuan. 


\section{DAFTAR PUSTAKA}

Gunawan,P.R.(2013a). Pendekatan pembelajaran realistic mathematic education (RME). [Online]. Diakses dari: http://proposalmatematika23.blogspot.co $\underline{\mathrm{m} / 2013 / 05 / \quad \text { pendekatan-pembelajaran }}$ realistic.html.

Humardani (2010). Implementasi model Contextual Teaching and Learning (CTL) untuk meningkatkan pemahaman siswa pada materi luas dan keliling lingkaran di kelas VI SDN 1 Bojongkulon Kec. Susukan Kabupaten Cirebon. (Skripsi). Universitas Pendidikan Indonesia.

Jufriyah, R. (2008). Penerapan pendekatan kontekstual untuk meningkatkan kemampuan memecahkan masalah soal cerita operasi hitung campuran siswa kelas IV SDN 1 Lungbenda Kecamatan Palimanan Kabupaten Cirebon. (Skripsi). Universitas Pendidikan Indonesia

Peraturan Menteri Pendidikan Nasional (2006a). Kurikulum 2006 (Peraturan Menteri Pendidikan Nasional Republik Indonesia Nomor 22 Tahun 2006 tentang Standar Isi untuk satuan Pendidikan Dasar. Jakarta: Depdiknas

Peraturan Menteri Pendidikan Nasional (2006b). Peraturan Menteri Pendidikan Nasional Republik Indonesia Nomor 23 Tahun 2006 Tanggal 23 Mei 2006. Jakarta: Depdiknas

Suryanto, dkk. (2010). Sejarah pendidikan matematika realistik Indonesia (PMRI). Yogtakarta: Dikti.

Tarigan, D. (2006). Pembelajaran matematika realistik. Jakarta: Depdiknas.

Sembiring. R., Hoogland,K., \& Dolk, M (2010) Introdution to: A Decade of PMRI in Indonesia. Bandung, Utrechs: APS International

Sembiring. R. K (2007) Perkembangan Pendidikan Matematika Realistik Indonesia (PMRI) di Indonesia.Paper presented at the Universitas Syiah Kuala -Nasional Seminar on Workshop PMRI.

Suyadi. (2013). Panduan Penelitian Tindakan Kelas. Jogjakarta: DIVA Press 